\title{
STUDI PEMBUATAN PIKEL CABAI KERITING UTUH \\ (Capsicum annuum var.glabiusculum)
}

\author{
Rifni Novitasari, S.Tp., MP \\ Dosen Teknologi Pangan UNISI, Riau \\ rifninovi@gmail.com
}

\begin{abstract}
Abstrak
Penelitian dengan judul studi pembuatan pikel cabai keriting utuh ini bertujuan untuk mencegah kerusakan cabai keriting dan memperpanjang umur simpannya. Pembuatan pikel dimulai dengan cara sortasi bahan baku yakni cabai merah keriting dengan ukuran sedang, yang kemudian dibuang bagian tangkainya, lalu dicuci bersih dengan menggunakan air mengalir. Kemudian di blanching dengan menggunakan air yang dimasak dan telah mencapai suhu $820 \mathrm{C}$ selama 5 menit, kemudian dimasukkan ke dalam air dingin sesaat lalu ditiriskan dengan tujuan proses pemasakan akibat proses blanching terhenti, sehongga cabai tidak melunak. Selanjutnya dilakukan proses Perendaman dalam larutan $\mathrm{CaCl} 20,2 \%$ selama 30 menit \& ditiriskan dengan tujuan untuk memperkuat tekstur cabai.Kemudian cabai ditiriskan kembali dan dilakukan proses perendaman dalam larutan garam $5 \%+$ gula $1 \%+$ asam asetat $1,5 \%$ + asam sitrat $0,15 \%$ + irisan bawang putih 8 gr, yang telah dilarutkan secara merata dengan cara memasaknya selama 2 menit dengan tujuan agar larutan tercampur dengan rata, Perendaman dilakukan selama 7 hari, dan setelah 7 hari dibuang buihnya lalu dilakukan proses pengemasan pikel.Pikel yang dihasilkkan setelah di analisa secara kimia memiliki pH 3,8 dengan kadar vitamin $\mathrm{C}$ berkisar 26,4 mg dengan tekstur yang masih kokoh seperti bahan bakunya, warna merah khas cabai yang cerah serta aroma dan rasa khas pikel pada umumnya berdasarkan penilaian objektif.
\end{abstract}

Kata Kunci : Pikel, Cabai Keriting, Pengawetan

\section{PENDAHULUAN}

Cabai besar (Capsicum annuum) merupakan komoditas holtikultura yang telah lama dibudidayakan oleh petani karena digunakan oleh semua lapisan masyarakat baik untuk kebutuhan rumah tangga maupun untuk perkembangan industri makanan dan obat-obatan. Permintaan terhadap cabai cukup tinggi, relatif kontinu dan cenderung meningkat merupakan alasan yang kuat bagi petani untuk tetap membudidayakan cabai.
Jenis cabai keriting (Capsicum annuum var.glabiusculum) banyak dihasilkan di Indonesia, yang produksinya berdasarkan pendataan mengalami peningkatan dari tahun ke tahun.

Rasa pedas yang dominan menyebabkan cabai besar, khususnya cabai merah dan cabai keriting lebih diminati untuk dikonsumsi sebagai bumbu atau penyedap masakan untuk skala rumah tangga, terutama oleh masyarakat di daerah Sumatera Barat. 
Rasa pedas tersebut disebabkan oleh kandungan capsaicin (Santika, 2004).

Menurut Dadang (1997), senyawa capsaicin $\left(\mathrm{C}_{18} \mathrm{H}_{27} \mathrm{NO}_{3}\right)$ dalam cabai besar mengandung 5 komponen aktif capsaicinoid, yaitu; nordihidro capsaicin, capsaicin, dihidro capsaicin, homo capsaicin dan homo dihidro capsaicin. Komponen-komponen tersebut dapat dijadikan ramuan untuk pengobatan sirkulasi darah yang kurang lancar seperti pada tangan, kaki dan jantung.

Lebih lanjut beliau menguraikan bahwa kandungan capsaicin pada cabai juga mengandung berbagai khasiat dalam bidang kesehatan lainnya, yaitu ;dapat bersifat analgesik sehingga dapat meringankan rasa pegal dan dingin akibat rematik dan encok; sebagai anti alergi akibat kedinginan; bersifat mukokinetik yang dapat mengurangi, mengatur dan mengeluarkan lendir dari paru-paru sehingga bisa menyembuhkan penyakit bronchitis, influensa, masuk angin, sinusitis dan asma.

Kandungan capcikidin yang terdapat pada biji menurut beliau juga mampu mempelancar sekresi asam lambung dan mencegah infeksi sistem pencernaan. Semacam minyak atsiri yang disebut capsicol juga dapat dimanfaatkan untuk mengganti minyak kayu putih. Kandungan kalsium dan fosfornya yang tinggi dapat membantu pertumbuhan tulang dan gigi. Cabai secara umum juga mengandung flavonoid dan antioksidan yang dapat melindungi tubuh dari kanker dan penyakit lain.

Walaupun tingkat permintaan cabai tinggi, pada kenyataannya harga cabai dipasaran selalu berfluktuasi. Hal ini disebabkan karena produksi cabai juga mengalami peningkatan yang tidak sedikit. Ketidakstabilan harga inilah yang menjadi momok petani cabai dalam menjalankan usahanya. Layaknya penjudi, petani cabai akan meraup untung apabila harga cabai dipasaran tinggi, tapi petani cabai juga sering meratapi kerugiannya yang tidak sedikit saat harga cabai tidak dapat menutup modal usaha yang telah mereka keluarkan. Survey harga yang telah dilakukan pada bulan Mei menunjukkan bahwa harga cabai di Kota Tembilahan turun drastis dari harga Rp. $48.000,-/ \mathrm{Kg}$ menjadi Rp. 20.000,-/Kg saat produksi cabai di daerah Jawa meningkat. Bahkan di daerah Jawa itu sendiri harga cabai besar hanya mencapai Rp. 16.000,$/ \mathrm{Kg}$.

Pikel adalah hasil pengolahan buah atau sayuran dengan menggunakan garam dan asam dengan atau tanpa penambahan gula dan rempah-rempah sebagai bumbu (Vaughn, 1982). Terdapat 2 jenis pikel, yaitu pikel jadi dan pikel setengah jadi (Koswara, 2009). Pikel jadi adalah buah-buahan dan sayursayuran yang diawetkan dalam vinegar (larutan cuka), baik dengan penambahan rempah-rempah. Pikel jadi terbagi dua, yaitu pikel jadi tanpa fermentasi dan dengan fermentasi. Pikel jadi tanpa fermentasi banyak diterapkan dalam pembuatan pikel skala industry, Menurut Andress et al., (2015), pikel tanpa terfementasi akan memiliki rasa lebih baik jika didiamkan beberapa minggu setelah ditutup. Keuntungan dari pikel jadi tanpa fermentasi adalah proses pembuatannya yang cepat (hanya dalam beberapa jam), rasa asam lebih tajam, tidak perlu pengawasan lebih dalam pembuatannya dan peluang kegagalan dalam proses produksi dapat diminimalisir (Andress et al., 2015).

Asam yang digunakan pada pembuatan pikel pada umumnya adalah asam asetat (cuka). Pikel harus memiliki $\mathrm{pH}$ akhir 4,6 atau lebih rendah.

Cabai sebagai hasil holtikultura mudah mengalami perubahan fisiologis, 
kimia dan fisik bila tidak ditangani dengan tepat sehingga akan terjadi penurunan mutu sebagai dampak akibat kerusakan mekanis, fisiologis, kimia dan biologis pascapanen dari cabai tersebut. Menurunnya kualitas cabai menyebabkan penurunan nilai jual dari cabai itu sendiri.

Untuk mencegah kerusakan cabai keriting dan memperpanjang umur simpannya saat harga cabai keriting turun dipasaran, maka dilakukan pengolahan cabai menjadi berbagai produk olahan. Produk olahan cabai yang telah ada seperti cabai kering, tepung/ bubuk cabai, oleoresin cabai umumnya selain mengalami susut berat juga mengalami penurunan kadar capcaisinnya saat pengolahan. Hal ini disebabkan karena proses pengeringan dan pembuangan biji cabai yang menyebabkan rasa pedas tersebut saat pengolahan. Berdasarkan uraian di atas, maka dilakukan "Studi Pembuatan Pikel Cabai Keriting (Capsicum Annuum Var.Glabiusculum) Utuh “.

\section{TINJAUAN PUSTAKA}

\section{Tanaman Cabai Merah Keriting (Capsicum Annuum Var.Glabiusculum)}

Tanaman cabai mula-mula tumbuh di daratan Amerika Selatan dan Amerika Tengah, termasuk meksiko, kira-kira sejak 2500 tahun sebelum Masehi (Wiryanta, 2002).

Menurut Vos (1994), tanaman cabai merupakan tanaman semak yang tergolong sebagai ranaman tahunan, tetapi umumnya diusahakan sebagai tanaman setahun baik di daerah-daerah beriklim sedang maupun di daerah tropis. Tanaman ini merupakan tanaman rempah-rempah yang mempunyai nilai ekspor tinggi. Cabai dikenal didunia karena peranannya yang penting didalam masakan. Disamping itu tanaman cabai merupakan tanaman sayuran utama yang ditanam secara meluas di negara-negara Asia Tenggara seperti Indonesia, Malaysia Thailand dan negara Asia lainnya seperti India, Korea, dan Cina.

Tanaman cabai umumnya berbentuk perdu, dari suku (famili) terong-terongan (Solanaceae). Tanaman cabai dapat tumbuh di dataran rendah, menengah sampai dataran tinggi sekitar $2.500 \mathrm{~m} \mathrm{dpl}$.

Untuk pertumbuhan optimal, tanaman cabai membutuhkan intensitas cahaya matahari sekurang-kurangnya 1012 jam, dengan suhu ideal untuk perkecambahan benih cabai antara $25^{\circ} \mathrm{C}$ $30^{\circ} \mathrm{C}$, sedangkan untuk pertumbuhannya berkisar $24^{\circ} \mathrm{C}-28^{\circ} \mathrm{C}$, kelembapan relatif $80 \%$ dan pH ideal 6-7 (Wiryanta, 2002).

Salah satu varietas cabai merah yang potensial dibudidayakan dan disukai oleh konsumen adalah cabai keriting. Cabe merah keriting ukurannya lebih kecil dari cabai biasa, tetapi rasa dan aromanya dan rasanya lebih pedas dan tajam dibandingkan dengan cabai merah biasa. Menurut Wiryanta (2002), tanaman cabai merah keriting diklasifikasikan sebagai berikut :
Kingdom : Plantae
Divisi : Spermatophyta
Subdivisi : Angiospermae
Kelas : Dicotyledoneae
Ordo : Tubiflorae (Solanales)
Famili : Solanaceae
Genus : Capsicum
Species : Capsicum annum
Var.Glabiusculum

Meskipun varietas lokal, cabai keriting dengan beberapa kelebihannya mampu bersaing dengan cabai hot beauty (impor). Kelebihan cabai keriting dibanding cabai jenis lainnya selain dari rasanya yang sangat pedas Cabai jenis ini juga tahan terhadap serangan penyakit keriting daun. Disamping itu bibit cabai keriting lebih 
mudah didapat dari turunannya dan tidak mengalami penurunan produksi meskipun ditanam berulang kali. Adapun ciri-ciri cabai keriting ini adalah :

$\checkmark$ bentuk berkelok-kelok dengan permukaan buah tidak merata (keriting).

$\checkmark$ buah muda berwarna hijau, tua atau matang berwarna merah.

$\checkmark$ tanaman tegak, ukuran daun lebar dan besar dibandingkan cabai biasa. $\checkmark$ warna daun hijau tua bertabur warna putih.

Persyaratan mutu yang ditetapkan untuk cabai keriting masih mengacu pada SNI cabai merah segar yang masih merupakan satu kelompok komoditas yaitu SNI 01 - 4480 - 1998, Persyaratan mutu cabai merah digolongkan dalam 2 jenis mutu yaitu Mutu I dan Mutu II. Persyaratan mutu cabai merah dalam SNI meliputi keseragaman, bentuk, kadar kotoran, tingkat kerusakan dan persentase buah busuk.

Tabel 1. Syarat Mutu Cabai Merah Segar Sesuai dengan SNI 01-4480-1998

\begin{tabular}{|c|c|c|c|c|}
\hline \multirow{2}{*}{ Jenis Uji } & \multirow[b]{2}{*}{ Satuan } & \multicolumn{3}{|c|}{ Persyaratan } \\
\hline & & Mutu I & Mutu II & Mutu III \\
\hline Keseragaman warna & $\%$ & $\begin{array}{c}\text { Merah } \\
3(95)\end{array}$ & $\begin{array}{c}\text { Merah } \\
3(95)\end{array}$ & $\begin{array}{c}\text { Merah } \\
3(95)\end{array}$ \\
\hline Keseragaman Bentuk & $\%$ & $\begin{array}{c}\text { Seragam } \\
(98)\end{array}$ & $\begin{array}{c}\text { Seragam } \\
(98)\end{array}$ & $\begin{array}{c}\text { Seragam } \\
(98)\end{array}$ \\
\hline Keserangaman ukuran & $\%$ & $\begin{array}{c}\text { Normal } \\
(98)\end{array}$ & $\begin{array}{c}\text { Normal } \\
(96)\end{array}$ & $\begin{array}{c}\text { Normal } \\
(95)\end{array}$ \\
\hline \multicolumn{5}{|l|}{ a. Cabai merah besar segar } \\
\hline - Panjang buah & $\mathrm{cm}$ & $12-14$ & $9-11$ & $<9$ \\
\hline - Garis tengah pangkal & $\mathrm{cm}$ & $1,5-1,7$ & $1,3-<1,5$ & $<1,3$ \\
\hline \multicolumn{5}{|l|}{ b. Cabai merah keriting } \\
\hline - Panjang buah & $\mathrm{cm}$ & $>12-17$ & $10-<12$ & $<10$ \\
\hline - Garis tengah pangkal & $\mathrm{cm}$ & $>1,3-1,5$ & $1,0-<1,3$ & $<1,0$ \\
\hline Kadar kotoran & $\%$ & 1 & 2 & 5 \\
\hline \multicolumn{5}{|c|}{ Tingkat Kerusakan dan Busuk } \\
\hline a. Cabai merah besar & $\%$ & 0 & 1 & 2 \\
\hline b. Cabai merah keriting & $\%$ & 0 & 1 & 2 \\
\hline
\end{tabular}

\section{Komposisi Kimia Cabai Merah Keriting}

Menurut Lukmana (2004) cabai mengandung kurang lebih $1.5 \%$ (biasanya antara $0.1-1 \%$ ) rasa pedas. Rasa pedas tersebut terutama disebabkan oleh kandungan capcaisin dan dihidrocapcaisin. Kandungan homocap- caisin dan homodihidro capcaisin terdapat dalam konsentrasi sangat kecil.

Lebih lanjut beliau mengatakan bahwa pada saat ini, telah ditemukan kandungan karatenoid (capsanthin, capsorubin, carotene dan lutein), lemak $(9-17 \%)$, protein $(12-15 \%)$, vitamin A dan $\mathrm{C}$, serta sejumlah kecil minyak menguap. Kandungan dalam minyak 
menguap mencapai 125 komponen dan 24 di antara komponen tersebut sudah dapat diidentifikasi.

Tandon, Dravid dan Siddapa (1962) cit Adinata (2005) menyatakan bahwa komponen pemberi rasa pedas (capsainoids) sebagian besar terdapat dalam perikarp $(89,20 \%)$, di bagian biji $10,80 \%$ dan tidak ditemukan pada bagian tangkai.

Menurut Purseglove, Brown, Green dan Robbins (1981) cit Adinata (2005) bahwa tingkat kepedasan cabai akan meningkat dengan naiknya tingkat kematangan. Cabai yang ditanam pada musim panas (kemarau) akan memberikan tingkat kepedasan yang lebih tinggi bila dibandingkan dengan cabai yang ditanam pada musim dingin (penghujan).

Cabai yang digunakan orang sebagai pembangkit selera makan (appetizer) disebabkan karena adanya kandungan minyak atsiri yang ditimbulkan cabai saat dikunyah atau oleh aromanya yang tercium oleh hidung sebelum disantap. Selain itu cabai juga mengandung capsikidin dan senyawa capsikol (pengganti minyak kayu putih) yang sama-sama berperan dalam ilmu pengobatan (Wiryanta, 2002).

Adapun kandungan gizi cabai merah secara umum diperlihatkan pada tabel 2 .

Tabel 2. Kandungan gizi cabai merah segar per 100 gram

\begin{tabular}{|c|l|c|}
\hline No & \multicolumn{1}{|c|}{ Kandungan Gizi } & Satuan \\
\hline 1 & Kalori & $31,0 \mathrm{kal}$ \\
2 & Protein & 1,0 gram \\
3 & Lemak & $0,3 \mathrm{gram}$ \\
4 & Karbohidrat & $7,3 \mathrm{gram}$ \\
5 & Kalsium & $29,0 \mathrm{mg}$ \\
6 & Fosfor & $24,0 \mathrm{mg}$ \\
7 & Besi & $0,5 \mathrm{mg}$ \\
8 & Vitamin A & $470(\mathrm{SI})$ \\
9 & Vitamin C & $18,0 \mathrm{mg}$ \\
10 & Vitamin $\mathrm{B}_{1}$ & $0,05 \mathrm{mg}$ \\
11 & Vitamin B & $0,03 \mathrm{mg}$ \\
12 & Niasin & $0,20 \mathrm{mg}$ \\
13 & Capcaisin & $0,1-1,5 \%$ \\
14 & Pektin & $2.33 \%$ \\
15 & Pentosan & $8.57 \%$ \\
16 & Pati & $0,8-1,4 \%$ \\
\hline
\end{tabular}

Sumber : Buah dan Sayuran untuk Terapi Herbs, diolah.

Warna cabai Rubatzky dan Yamaguci (1999) sangat bervariasi : hijau, kuning atau bahkan ungu ketika muda, dan kemudian berubah menjadi merah, jingga, kuning atau pencampuran warna-warna tadi dengan meningkatnya umur cabai. Warna hijau disebabkan karena adanya klorofil, sedangkan merah dan kuning disebabkan oleh adanya karotenoid, dan ungu disebabkan oleh antosianin. Warna coklat disebabkan oleh keberadaan klorofil bersamaan dengan sintesis likopen dan beta-karoten. Pada sebahagian kultivar komersial, warna coklat adalah peralihan ke fase matang. 


\section{Pikel Cabai}

Pikel merupakan cara pengawetan sayuran atau buah dengan menggunakan asam, berupa asam hasil fermentasi ataupun dengan penambahan cuka. Asam hasil fermentasi berasal dari proses fermentasi cairan buah atau sayuran itu sendiri (Ani Suryani, Erliza Hambali dan Sutanto, 2004).

Pikel atau acar adalah sayuran atau buah-buahan yang diawetkan dalam larutan garam yang kemudian dilakukan fermentasi asam laktat. Hampir semua jenis sayuran dapat difermentasi secara alami oleh bakteri asam laktat, karena sayuran mengandung gula yang diperlukan untuk pertumbuhan bakteri tersebut (Apandi, 1984 cit Sri Mulia Astuti, 2006).

Proses fermentasi sayuran dipengaruhi oleh berbagai faktor, seperti kondisi anaerobik, konsentrasi garam, suhu dan adanya bakteri asam laktat (Buckle, Edwards, Fleet dan Wootton, 1987). Fermentasi mula-mula terjadi dalam larutan tanpa gula, tetapi karena adanya tekanan osmosis dari garam ke dalam bahan, maka gula yang ada dalam bahan akan merembes ke larutan sehingga kadar gula dalam larutan meningkat. Selanjutnya terjadi fermentasi gula olehbakteri asam laktat yang menghasilkan asam laktat.

Sri Mulia Astuti

menuturkan bahwa bakteri asam laktat merupakan bakteri yang diperlukan dalam fermentasi sayuran. Bakteri ini secara alami terdapat pada sayuran itu sendiri. Pemanfaatan bakteri ini yang dikombinasikan dengan pemberian garam dan suhu yang tepat akan menghasilkan produk fermentasi yang bermutu baik.

Daulay dan Rahman (1992) mengemukakan bahwa kontrol alami yang mempengaruhi populasi mikroorganisme yang terdapat pada fermentasi sayuran adalah konsentrasi garam, dan suhu dari larutan garam, tersedianya bahan-bahan terfermentasi serta jumlah dan jenis mikroorganisme yang terdapat pada awal fermentasi. Kecepatan fermentasi berkorelasi langsung dengan konsentrasi garam dan suhu dari larutan garam.

Berdasarkan cita rasanya pikel dikelompokan menjadi pikel asin (dill pickle), pikel manis (sweet pickle) dan pikel asam (sour pickle) dan berdasarkan cara pembuatannya, pikel dikelompokan menjadi pikel tanpa fermentasi dan pikel fermentasi. Selanjutnya pikel terfermentasi dikelompokan menjadi pikel yang difermentasi dalam larutan garam encer (pikel dill), pikel yang difermentasi dalam larutan garam pekat (pikel stok garam), dan pikel yang difermentasi dengan menggunakan kristal garam (dry salting) dengan konsentrasi rendah seperti pada pembuatan sauerkraut (Daulay et al, 1992).

Sedangkan Suryani et al (2004) mengelompokan pikel berdasarkan jenis larutan perendam yang digunakan, yaitu ; pikel asin (brined pickle) yang dibuat menggunakan asam yang berasal dari hasil fermentasi cairan buah atau sayuran yang diberi garam; pikel segar (fresh pack pickle) atau disebut pikel asam yang pada pembuatannya menggunakan cuka sebagai bahan pengasamnya; dan pikel manis (sweet pickle) yang menggunakan larutan campuran gula, garam dan cuka dengan penambahan beberapa bahan tambahan.

Pikel cabai merupakan salah satu diversifikasi olahan cabai yang bertujuan selain untuk mengawetkan cabai juga untuk memudahkan konsumen menggunakan cabai untuk berbagai keperluan. Beberapa tahun terakhir ini telah dilakukan berbagai penelitian pembuatan pikel cabai yang difokuskan 
untuk memenuhi kebutuhan industri makanan jadi seperti burger, salad, martabak telur dan lain-lain. Dengan pangsa pasaran industri makanan jadi, maka kebanyakan metode pembuatan pikel menggunakan larutan campuran gula, garam dan cuka dengan penambahan beberapa bahan tambahan (Suryani et al, 2004).

\section{Blanching}

Blanching adalah perlakuan panas pada bahan dengan cara merendam bahan dalam air panas atau memberikan uap panas. Blanching bertujuan untuk menonaktifkan enzim terutama katalase dan peroksidase, melembekan bahan, dan menghilangkan gas-gas yang ada dalam sel serta jaringan sehingga kualitas bahan akhir meningkat. Blanching juga menyebabkan bahan menjadi bersih, mengurangi populasi bakteri, serta mempertajam aroma dan warna. Biasanya aroma bahan yang tidak disukai dapat dihilangkan dan warna asli bahan dan sayuran yang berwarna hijau dan kuning akan tampak lebih tajam (Sukmaji, 1988).

Menurut Dina Agoes $\mathrm{S}$ dan Lisdiana (1995), blanching merupakan teknik melunakkan bahan pangan seperti sayuran dalam air panas yang suhunya dibawah $100^{\circ} \mathrm{C}$. Lamanya perendaman di dalam air panas tergantung pada tekstur jenis sayuran atau buah, tetapi tidak lebih dari 10 menit. Oleh karena itu, metode blanching cocok digunakan untuk melunakkan sayuran yang tidak terlalu keras.

Blanching dengan menggunakan bahan kimia tertentu berguna untuk memperpanjang daya simpan (Sudarsih dan Ratriningsih, 1999). Sedangkan Muchtadi dan Sugiono (1999) cit Diana Puspita (2007) menuturkan bahwa perendaman dalam larutan sulfit terutama ditujukan untuk memperbaiki warna atau mengurangi pencoklatan. Selain menggunakan medium air atau uap air, blanching juga dapat dilakukan dengan menggunakan medium air yang ditambahkan dengan senyawa sulfit. Penambahan bahan kimia ini terutama untuk memperbaiki warna produk.

Blanching menggunakan medium air memungkinkan kehilangan komponen terlarut bahan lebih besar jika dibandingkan dengan menggunakan uap air. Blanching dengan menggunakan medium air membutuhkan waktu yang lebih singkat dibandingkan bila menggunakan uap air karena penetrasi panas lebih cepat terjadi pada medium cair (Muchtadi et al, 1999 cit Diana Puspita, 2007).

Blancing bertujuan untuk melunakkan buah cabai dan membunuh mikroorganisme seperti jamur atau bakteri. Caranya, cabai dimasukkan ke dalam air steril yang mendidih selama 2 - 3 menit. Setelah itu cabai langsung dicuci dengan air dingin untuk menghilangkan senyawa yang larut dan berwarna. Blancing ini sekaligus bertujuan untuk memelihara kualitas cabai (Abdjad Asih Nawangsih, Imdad dan Wahyudi, 2003).

Dalam Proses blanching, ada beberapa larutan yang dapat digunakan untuk merendam cabai :

$\Rightarrow$ Cabai merah direndam dalam air mendidih yang diberi larutan $\mathrm{NaHSO}_{3}$ (Natrium Bisulfit) selama \pm 5 menit.

Cabai merah direndam dalam air mendidih yang diberi Kalsium Metabisulfit $(0,2 \%)$ selama \pm 5 Menit.

Cabai direndam dalam emulsi "Dispol". Emulsi ini terdiri dari $\mathrm{K}_{2} \mathrm{CO}_{3} 2,5 \%$, minyak kelapa $1,0 \%$, gom akasia 0,1\% dan BHA 0,001\% (Sudarsih et al, 1999). 
Menurut Desrosier (1988), sulfurisasi adalah perlakuan dengan penambahan sulfur dioksida yang bertujuan mempertahankan $B$ karoten dan juga mencegah kerusakan oleh mikroba. Lebih lanjut Sulaswati dan Roestamsjah (1991) cit Diana Puspita (2007) menyatakan bahwa sulfur dioksida juga berfungsi memperbaiki retensi asam askorbat dalam buah yang dikeringkan.

\section{Penggunaan Pengawet Pangan dengan Aditif Kimia}

Komite Gabungan Ahli FAO dan WHO merumuskan definisi dari zat aditif bahan pangan sebagai suatu substansi bukan gizi yang ditambahkan ke dalam bahan pangan dengan sengaja, yang pada umumnya dalam jumlah kecil, untuk memperbaiki kenampakan, cita rasa, tekstur atau sifat-sifat penyimpanannya. Substansi yang ditambahkan terutama yang mempunyai nilai gizi seperti vitamin dan mineral tidak dimasukan ke dalam golongan ini (Desrosier, 1988).

Lebih lanjut Federal Food, Drug and Cosmetic Act menyatakan bahwa setiap zat kimia yang bila ditambahkan ke dalam bahan pangan cenderung untuk mencegah atau menghambat kerusakannya disebut zat pengawet kimia. Hal yang terpenting yang perlu diperhatikan pada penggunaan bahan kimia untuk pengawet sayur-sayuran dan buah-buahan adalah :

1. Zat kimia yang ditambahkan mampu memelihara kualitas gizi yang dikandungnya.

2. Zat tersebut dapat meningkatkan kualitas dan stabilitas daya simpan.

3. Dapat membuat produk lebih menarik.

4. Lebih diutamakan untuk membantu proses pengolahan.
5. Tidak membahayakan kesehatan konsumen.

Pada proses pembuatan pikel cabai, ada beberapa zat kimia yang ditambahkan, antara lain :

\section{Garam dapur (Natrium klorida)}

Proses penting dalam pembuatan pikel, khususnya pikel cabai adalah penggaraman. Garam berfungsi sebagai bahan untuk menarik air dan zat gizi dari jaringan bahan yang difermentasi untuk pertumbuhan bakteri pembentuk asam laktat (Aprianto, 1984 cit Sri Mulia Astuti, 2006).

Garam dapur dalam keadaan murni tidak berwarna , tetapi kadang-kadang berwarna kuning kecoklatan yang berasal dari kotoran-kotoran yang ada didalamnya.

Sebagian besar pembuatan pikel lebih menyukai teknik penggaraman dengan larutan garam encer atau pekat daripada metode penggaraman kering yang biasanya digunakan untuk memfermentasi mentimun. Larutan garam encer mempunyai konsentrasi garam antara $25^{\circ}$ sampai $30^{\circ}$ salometer digunakan untuk permulaan fermentasi dan larutan garam pekat dengan konsentrasi garam $40^{\circ}$ salometer atau lebih pada umumnya digunakan untuk penyimpanan pikel stok garam terfermentasi atau untuk memulai fermentasi sayur-sayuran lain yang dicampur dengan mentumun untuk membuat produk pikel campuran (Daulay et al, 1992).

Pada pembuatan pikel konsentrasi garam yang digunakan adalah sebesar 5 $-8 \%$, karena konsentrasi garam tersebut sangat cocok untuk pertumbuhan asam laktat.

Garam yang mempunyai densitas bervariasi (flake salt) tidak direkomendasikan dalam pembuatan pikel, Sedangkan garam yang dikurangi 
kandungan ion $\mathrm{Na}+$ nya (Lite salt) dapat digunakan untuk membuat pikel yang diproses cepat(fresh pack pickles), tetapi tidak disarankan menggunakan garam ini untuk pikrl yang difermentasi (Anonim, 2010).

\section{Natrium benzoat}

Ciri-ciri natrium benzoat adalah berbentuk serbuk atau kristal putih, halus, sedikit berbau, berasa payau dan pada pemanasan yang tinggi akan meleleh atau terbakar (Tri margono, Detty Suryati dan Sri Hartinah, 1993).

Natrium benzoat merupakan jenis bahan pengawet yang digunakan dalam proses pembuatan pikel dan sudah banyak penggunaan untuk produk makanan dan minuman lainnya. Penambahan natrium benzoat berfungsi sebagai bahan pengawet dan sangat efektif untuk menghambat pertumbuhan khamir dan bakteri.

Menurut Desrosier (1988), benzoat pada umumnya efektif terhadap khamir dan jamur daripada bakteri pada kafar $0,1 \%$ atau kurang dari yang diperkenankan. Benzoat pada kadar $0,1 \%$ dalam bahan pangan dapat menghasilkan rasa seperti merica atau rasa pedas atau rasa sengak.

\section{3. $\mathrm{CaCl}_{2}$}

Ani Suryani (2004) mengungkapkan bahwa $\mathrm{CaCl}_{2}$ berbentuk kristal dan berwarna putih. $\mathrm{CaCl}_{2}$ digunakan sebagai bahan campuran perendam bahan baku pikel. Fungsinya untuk memperkuat tekstur agar tetap terlihat keras.

Pengolahan bahan makanan yang berasal dari tumbuhan sering menghasilkan tekstur yang berubah menjadi lunak. Hal ini akibat perlakuan pada saat proses pengolahan atau pemanasan. Saat pemanasaan, komponen dinding sel buah dan sayuran mengalami proses penguraian. Akibatnya jaringan menjadi lunak. Untuk mempertahankan kerenyahan pangan olahan, maka dapat dilakukan penambahan zat pengeras pada saat pengolahan (Fatah dan Bachtiar, 2004 cit Sundari Eka Wahyu Tambunan 2006).

Lebih lanjut dikatakan bahwa perendaman dengan larutan $\mathrm{CaCl}_{2}$ berfungsi untuk menguatkan tekstur buah atau sayuran yang diolah menjadi produk olahan sehingga lebih kuat dan renyah. Perubahan ini disebabkan adanya senyawa kalsium dalam kapur yang berpenetrasil ke dalam jaringan buah atau sayuran. Akibatnya struktur jaringan buah atau sayuran menjadi lebih kompak berkat adanya ikatan baru antara kalsium dan jaringan dalam buah atau sayuran. Selain itu, penambahan $\mathrm{CaCl}_{2}$ juga bermanfaat untuk menetralkan warna coklat yang sering muncul pada buah atau sayuran, baik setelah pengupasan maupun setelah perendaman dengan bahan kimia.

Menurut Indeswari (1991) cit Sundari Eka Wahyu Tambunan (2006), penambahan garam-garam kalsium yang berlebihan dapat menghalangi pematangan buah tiga kali lipat pematangan normal. Dengan terhalangnya proses pematangan maka tekstur buah tidak menjadi lunak ataupun lembek. Selain itu keuntungan dari kalsium adalah kalsium tidak bersifat toksid atau beracun.

Keefektifan garam kalsium tergantung pada kandungan pektin yang ada pada buah dan sayuran. Selain itu garam kalsium pemakaiannya tergantung juga pada ad atau tidaknya zat-zat pengikat kalsium, misalnya ion oksalat, ion sitrat dan lain-lain.

\section{Asam Asetat}

Asam mempunyai 2 pengaruh anti mikroorganisme yakni: pengaruhnya 
terhadap $\mathrm{pH}$, sifat keracunannya yang khas dari asam-asam yang tidak terurai yang beragam untuk asam-asam yang berlainan, Pada $\mathrm{pH}$ yang sama asam asetat lebih bersifat menghambat mikroorganisme tertentu dari pada asam laktat yang lebih menghambat daripada asam sitrat.

Asam asetat atau asam cuka adalah senyawa kimia asam organik sebagai pemberi rasa asam dan aroma dalam makanan. Asam asetat merupakan pengawet yang aktif menghambat pertumbuhan kapang dan juga bakteri pathogen yang berasosiasi dengan bahan pangan seperti produk roti dan pikel (Pundir dan Jain, 2010). Studi lain menyatakan bahwa asam asetat efektif menghambat khamir pembentuk film dan kapang dibandingkan bakteri (Lee, 2004). Dalam pembuatan pikel, biasanya asam asetat (asam cuka) yang ditambahkan umumnya adalah sebesar $5 \%$.

\section{Asam Sitrat}

Asam sitrat merupakan asam organik lemah yang ditemukan pada daun-daunan dan buah tumbuhan citrus. Swnyawa ini merupakan bahan pengawet yang baik dan alami selain digunakan sebagai penambah rasa masampada makanan dan minuman ringan.

Sifat asam sitrat mempunyai $\mathrm{pH}$ rendah, tidak berbau, dan tidak berwarna. Penggunaan asam sitrat selain karena harganya murah, juga mudah dimetabolisme tubuh dan mudah ditemukan dipasaran. Adapun penambahan asam sitrat yang dipernolehkan /100 gr makanan adalah 5 gr -40 gr.

\section{Gula pasir}

Kegunaan gula dalam bahan pangan tidak hanya sebagai pemanis alami saja, tetapi juga berfungsi sebagai pengawet, membantu dalam proses fermentasi, membantu dalam pembentukan warna sehingga dapat meningkatkan mutu produk.

Daya larut yang tinggi dari gula, kemampuan mengurangi keseimbangan relative $(\mathrm{Rh})$ dan mengikat airasalkah sifat-sifat yang menyebabkan gula dipakai dalam pengawetan bahan pangan. Gula apabila diberikan pada konsentrasi diatas $70 \%$ padatan terlarut, akan mampu memberikan stabilitas pengendalian pertumbuhan mikroorganisme pada suatu produk makanan. Penambahan gula sebagai pengawet bahan makanan berkisar antara $40 \%$ sampai dengan $70 \%$.

\section{METODOLOGI}

Peralatan yang digunakan dalam penelitian adalah botol kaca bekas, baskom plastik, ember pencuci, sarung tangan, kompor gas, panci dan timbangan. Sedangkan bahan yang digunakan adalah; cabai keriting utuh yang telah dibuang tangkainya, garam, gula, $\mathrm{CaCl}_{2}$, natrium benzoate, natrium metabisulfiy, asam asetat dan asam sitrat.

Pembuatan pikel dimulai dengan cara sortasi bahan baku yakni cabai merah keriting dengan ukuran sedang, yang kemudian dibuang bagian tangkainya, lalu dicuci bersih dengan menggunakan air mengalir. Setelah itu cabai ditiriskan.

Cabai yang telah agak kering dari proses penirisan kemudian di blanching dengan menggunakan air yang dimasak dan telah mencapai suhu $82^{\circ} \mathrm{C}$ selama 5 menit, kemudian dimasukkan ke dalam air dingin sesaat lalu ditiriskan dengan tujuan proses pemasakan akibat proses blanching terhenti, sehongga cabai tidak melunak. Selanjutnya dilakukan proses Perendaman dalam larutan $\mathrm{CaCl}_{2} \quad 0,2 \%$ 
selama 30 menit \& ditiriskan dengan tujuan untuk memperkuat tekstur cabai.

Kemudian cabai ditiriskan kembali dan dilakukan proses perendaman dalam larutan garam $5 \%+$ gula $1 \%+$ asam asetat $1,5 \%+$ asam sitrat $0,15 \%+$ irisan bawang putih $8 \mathrm{gr}$, yang telah dilarutkan secara merata dengan cara memasaknya selama 2 menit dengan tujuan agar larutan tercampur dengan rata, Perendaman dilakukan selama 7 hari, dan setelah 7 hari dibuang buihnya lalu dilakukan proses pengemasan pikel.

\section{HASIL DAN PEMBAHASAN}

Pikel cabai yang dihasilkan setelah diuji memiliki pH 3,8 yang masih kurang dari kisaran $\mathrm{pH}$ pikel yang seharusnya, Menurut Anon, a., (2015) pikel harus memiliki $\mathrm{pH}$ akhir 4,6 atau lebih.

Baerdasarkan hasil analisa kimia, pikel yang dihasilkan memiliki kadar vitamin C sebesar 26,4mg . Anonim (1952) menyatakan bahwa penambahan asam asetat yang semakin tinggi dapat mengoksidasi asam askorbatyang terdapat pada buah-buahan dan sayursayuran. Hal ini juga dipertegas oleh Purinton dan Schuck (1943) yang mengatakan peningkatan kadar asam akan diikuti dengan penurunan kadar asam askorbat.

Pikel yang dihasilkan secara objektif tidak memiliki perbedaan yang berarti dengan bahan bakunya setelah mengalami proses perendaman selama 7 hari. Pikel masih berwarna merah, dengan tekstur sekokoh bahan bakunya . Hal ini disebabkan sebelum proses perendaman selama 7 hari cabai merah direndam dulu dalam larutan $\mathrm{CaCl}_{2}$ selama beberapa menit. Larutan $\mathrm{CaCl}_{2}$ berfungsi untuk menguatkan tekstur buah atau sayuran yang diolah menjadi produk olahan sehingga lebih kuat dan renyah. Perubahan ini disebabkan adanya senyawa kalsium dalam kapur yang berpenetrasil ke dalam jaringan buah atau sayuran. Akibatnya struktur jaringan buah atau sayuran menjadi lebih kompak berkat adanya ikatan baru antara kalsium dan jaringan dalam buah atau sayuran. Selain itu, penambahan $\mathrm{CaCl} 2$ juga bermanfaat untuk menetralkan warna coklat yang sering muncul pada buah atau sayuran, baik setelah pengupasan maupun setelah perendaman dengan bahan kimia.

Kombinasi asam asetat dan asam sitrat yang digunakan saat perendaman serta penambahan garam dapur dan bumbu berupa bawang putih dalam larutan, menhasilkan pikel cabe dengan khas rasa dan oroma layaknya pikel pada umumnya.

\section{KESIMPULAN DAN SARAN}

\section{Kesimpulan}

Pikel yang dihasilkkan setelah di analisa secara kimia memiliki $\mathrm{pH} 3,8$ dengan kadar vitamin $\mathrm{C}$ berkisar 26,4 mg dengan tekstur yang masih kokoh seperti bahan bakunya, warna merah khas cabai yang cerah serta aroma dan rasa khas pikel pada umumnya berdasarkan penilaian objektif.

\section{Saran}

Lebih lanjut disarankan untuk melakukan penelitian lanjutan dengan perlakukan-perlakuan tertentu untuk memperbaiki nilai $\mathrm{pH}$ dan kandungan vitamin $\mathrm{C}$ yang dihasilkan sehingga diproduksi pikel cabai merah utuh yang mendekati pikel yang memenuhi ketetapan yang telah ditetapkan SNI 

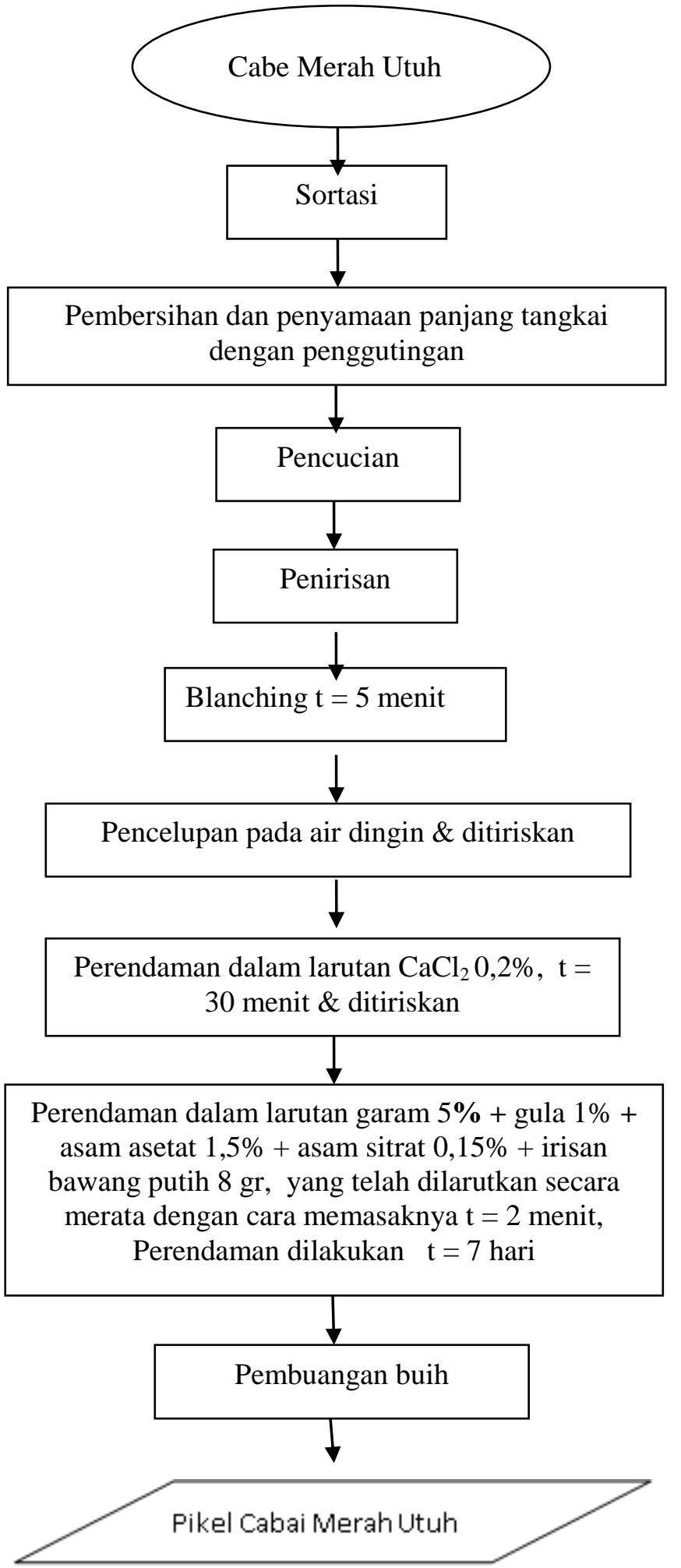

Gambar 1. Diagram Alir Pembuatan Pikel Cabai Keritin (Capsicum annuum var.glabiusculum) Utuh 


\section{DAFTAR PUSTAKA}

Adinata, Z. 2005. Pengaruh Perbandingan Pelarut Etanol dengan Bahan Terhadap Rendemen Beberapa Sifat FisikoKimia Oleoresin Cabe Rawit (Capsicum fruetescens L.). [Skripsi]. Fakultas Pertanian Universitas Andalas. Padang.

Ananta, R. 1997. Pengaruh Jenis Kemasan Terhadap Sifat FisikoKimia Bubuk Cabe (Capsicum annum L.). [Skripsi]. Fakultas Pertanian Universitas Andalas. Padang.

Andress, E.L., J. Harrison, dan K. Christian. 2015. Preserving Food Pickled Products. UGA Extension, Georgia.

Anonimus. 1952 c. Effect of Acetic Acid on the Oxidation of Ascorbic Acid in Fruits and Vegetables.Nature Journal Publishing Group :169934.

Anonimus. 2015 a. Pikel Mentimun atau Terong. Jurnal Teknologi Pangan dan Gizi 1(9):136-138.

Anonimus. 2015b. Teknologi Fermentasi Sayuran. Jurnal teknologi Industri Pangan.pdf. Diakses 6 Nopember 2016.

Asgar, A. dan D. Musaddad. 2006. Optimasi Cara, Suhu dan Lama Perebusan Pengeringan pada Wortel. BalaiPenelitian Tanaman Sayuran. Bandung.

Buckle, K.A., Edwards, R.A., Fleet, G.H. dan Wootton, M. 1985. Ilmu Pangan (terjemahan) Cetakan Pertama. UI Press. Jakarta

Dadang, W.I. 1997. Cabai dan Kesehatan. Trubus 332; $86-87$.

deMan, J. M. 1997. Kimia Makanan.Ed-2. ITB. Bandung

Diza, Y. 2000. Penggunaan Beberapa Bahan Nimia Alami dan Bahan Nimia Buatan dalam Usaha
Meningkatkan Daya Simpan Cabai Merah (Capsicum annum L.). [ Skripsi ]. Fakultas Pertanian Universitas Andalas. Padang.

Fellows, P. 2000. Food Processing Technology.Cambridge

Woodhead Publishing Limited Abington Hall

Ingham,B.H. 2002. Homemade Pickles and Relishes. UW Extension, Wisconsin.

Kartika dan Bambang. 1988. Pedoman Uji Inderawi Bahan Pangan. Yogyakarta: UGM

Koswara,S. 2009. Teknologi Pengolahan Sayuran dan Buah-Buahan

Lempsey, F.D. 2004. Cultivation Capsicum Sp.on Tropical Areal. University of Wageneingen, Wageneingen

Margono, T., Suryati, D. dan Hartinah, S. 1993. Pengawetan Produk Pangan. Buku Panduan Teknologi Pangan. PDII-LIPI. Jakarta.

Nataliningsih. 2010. Pengaruh Konsenterasi Garam dan Gula dalam pengolahan Pikel Bunga Pisang Ambon (Musa paradisiaca L.). Majalah Ilmiah Kopertis Wilayah IV. 20 (6):1-14.

Nawangsih, A.A., Imdad, H.P. dan Wahyudi, A. 2003. Cabai Hot Beauty. Ed. Revisi. Penebar Swadaya. Jakarta.

Puspita, D. 2007. Pengaruh Pengecilan Ukuran Cabai Merah (Capsicum annum L.). Sebelum

Dikeringkan Terhadap Lamanya Pengeringan dan Beberapa Karakter Bubuk Cabai Merah. [ Skripsi ]. Fakultas Pertanian Universitas Andalas. Padang.

Vaughn. 1982. Lactic Acid Fermentation of Cabbage, Cucumber, Olives and Other Produc In Industrial Microbiology.Fourth edition. AVI Publishing Co.Texas. 